\title{
GREEN SUPPLY CHAIN MANAGEMENT: PERSPECTIVES OF EMPLOYEES ON HOSPITALITY AND TOURISM SECTORS IN WEST SUMATERA
}

\author{
Meuthia \\ meuthia@eb.unand.ac.id \\ Ratni Prima Lita \\ Ranny Fitriana Faisal \\ Faculty of Economics, University of Andalas \\ Limau Manis Kec. Pauh, Padang City, West Sumatra 25163 \\ received: 10/6/19; revised: 3/9/19; published: 31/12/19
}

\begin{abstract}
This study aims to analyze employee perceptions regarding the implementation of Green Supply Chain Management (GSCM) in the hospitality \& tourism sector in West Sumatra. GSCM reflected by the dimensions of internal environmental management and green purchasing can be influenced by environmental orientation (internal and external environmental orientation). GSCM are tested at the second-order construct reflective level and first-order reflective level. Linkages between variables in this study were identified through quantitative explanatory research techniques by testing hypotheses. Non-probability sampling through purposive sampling method from 77 respondents is carried out directly in the two main sectors. The results showed that all hypotheses had a significant effect. Internal environmental orientation and external environmental orientation have a significant effect on GSCM. Interestingly, environmental orientation has become an important predictor affecting the application of GSCM in the hospitality and tourism sector in West Sumatra.
\end{abstract}

Keywords: green supply chain management; GSCM; environmental orientation; hospitality \& tourism sector; smartPLS 3.0

\section{INTRODUCTION}

Tourism industry is currently rocketing in Indonesia due to its improved performance. Additionally, it is regarded as one of the potential sector because of its service-centered activities. Tourism is one of the sustainable commodities that also engage the low social community level (Wem, 2018). The Indonesian Ministry of Tourism's technical expert from Tourism Marketing and Cooperation Division, predicts that Indonesia tourism prospect in 2019 will be bright due to a positive growth of travel propensity in countries from where international tourists come. It is in accordance with the positive projection rate of global tourist growth revealed by UNWTO. However, due to strict competition in tourism market, Indonesia has to face a big challenge (suaramerdeka.com, 2018).

People shall be involved in developing our tourism. Their role is considerably important to attract tourists. When local people actively participate in tourism, each tourism destination in Indonesia can be distinguished. Meanwhile, tourism is one of the sectors that can improve our local or national economy. Various tourism destinations in Indonesia have always been fully packed by tourists, either international or domestic, although the current economy is not conducive (Adinaya, 2018).

Minister of Tourism clarifies that according to the World Travel and Tourism Council (WTTC), tourism sector was ranked ninth as the highest growth sector. Tourism is apparently the fourth contributor to national devise following palm oil (CPO), oil and gas, and mining (coal). Furthermore, the Minister of Tourism also claimed that the number of the visits of international tourists continuously increased from 2015, 2016, and 2017 that was $9.7,11.5$, and 14 million respectively. Until August, the number of visits had reached 10.58 million (Wijanarko, 2018).

All countries in Indonesia are challenged to offer their tourism uniqueness, including West Sumatera. The performance of the government of West Sumatera in attracting tourists is starting to succeed. It can be observed from the notes conveying the number of tourists in West Sumatera in 2018 that was 8.1 million (Primasiwi, 2019). The increased number of tourists is proportional to the developed hospitality and tourism industries in the province. 
Well-developed hospitality and tourism industries will positively affect local economy. Hospitality and tourism industries include provision of food, beverages, and accommodation for tourists. The activities are usually conducted by hotels, home stays, restaurants, cafés, and other facilities that serve tourists during their vacation. Such activities can be optimized when the business management has owned a good supply chain management. As a tourism destination, West Sumatera should establish a good supply chain management in their hospitality and tourism sectors.

Strict business competition has stimulated green supply chain management as the follow-up of supply chain management. Consequently, technology and information processes are currently holding an important role to arrange strategies in respect of the strict competition and demand pressure from environment (Moori, Shibao, and Santos, 2018). Issues about the green supply chain management has drawn interests of many researchers and other professionals due to increased concerns of the impacts on environment largely caused by industry operation (Hashemi, Amir, and Tavana, 2015). They urge organizations to develop an innovative management to create a competitive excellence (Rao and Holt, 2005). A great change has altered a certain management environment type into more specific one. Organizations perform their operational activities in accordance with functional limits, resulting in an accountable environment during the product development. The activities include operation, logistics, and compliance monitoring with rules and regulations controlling solid waste (Srivastava, 2007).

Supply chain management (SCM) should be integrated and coordinated in business process. Moreover, we should balance our strategies on how to satisfy end clients (Green Jr., Whitten, and Inman 2008; Green Jr., McGaughey, and Casey, 2006; Cohen and Roussel, 2005; Ho, Au, and Newton, 2002). By the competition in supply chain level and end client demand, company should identify and adopt certain practices to make a competitive excellence and performance improvement in every supply chain (Green Jr, Whitten, and Inman, 2008).

Environmental preservation is necessary for the supply chain, because it is an indicator stating that company has implemented GSCM practices and built a cooperation with both suppliers and clients (Green Jr. et al., 2012). Manager should develop SCM knowledge and capabilities. They should focus on supply chain improvement to enhance the company performance. As manager's target in SCM strategy adoption is to satisfy end clients of the supply chain, they should be responsible for their company performance (Green Jr. et al., 2012).

Implementation of environmental preservation strategy demands company to directly cooperate with both suppliers and clients. After environmental sustainability has become the focus of strategy, producers can start implementing the sustainable practice and expect it to be able to improve environmental performances. GSCM adoption enhances the company capability to maintain environment and strengthen organization economy feasibility (Green Jr et al., 2012).

Additionally, manager should also analyze the contingency of organization's internal and external environments to apply the best strategy (Volberda et al., 2012; El-Masri et al. 2015). Chan (2010) argues that environmental orientation influences green supply chain management. The external factors can be economic situation, political factor, demographical trend, or industrial factor vulnerable against rapid changes (Brochado, Rita, and Margarido, 2016). Besides, external environmental factors are all situations while organization has no control over it (Urquidi and Ripoll, 2013). Moreover, internal environment orientation is the implementation of green supply chain management development as the organizations' imperative strategy through commitment and imperative supports from manager's senior and junior levels (Zhu, Sarkis, and Lai, 2008).

Tourism facilities usually spend natural resources to meet the high tourist demand. The highest consumption rate in hotel sectors is in water and energy resources. Meanwhile, most hotels have applied internal environmental management to enhance their environmental performance (Masa'deh et al., 2017). Environmental management system includes various company aspects; such as accountability, strategic planning, resources, procedure, and internal and external organization activities in accordance with the standards of ISO 14001. It is the dominant approach to manage various company environmental aspects in Indonesia (Chan, 2011; Mahadeen et al., 2016).

Chan et al. (2012) performed research to examine the effects of internal environmental orientation practice and external environmental orientation on green supply chain management. They figured out that both internal and external environmental orientations gave a positive and significant effect to green purchasing practice and client cooperation. Moreover, internal environmental orientation is more effective to support investment recovery practice. GSCM activities have significantly improved the company performance. It is necessary for the company to maintain their ecofriendly company culture and enhance their sensitivity to external environment i.e. demand from the stakeholders to realize a greener supply chain management.

The green supply chain management practice has a rapid development in the last decades from 1990s in hospitality and tourism industries (Buckley, 2012). Research on this topic significantly continues, especially that on eco-friendly practices in hotel industries (Nicholls and Kang, 2012; Jones et al., 2014). The research aims to assess employees' perspective on 
supply chain management that concerns of their work environment. It encourages us to investigate the correlation between environmental orientation construct (internal and external) and green supply chain management in hospitality and tourism sectors in West Sumatera.

The research aims to: (1) investigate employee perception on the implementation of green supply chain management in hospitality and tourism sectors in West Sumatera and (2) analyze the two hypotheses including: the effect of internal environmental orientation on the green supply chain management and the effect of external environmental orientation on the green supply chain management in the hospitality and tourism sectors in West Sumatera.

\section{METHODS}

The research applied quantitative approach by explanatory design through hypothesis testing. Meanwhile, data used in the research were primary data collected by survey. The survey was conducted by distributing questionnaires to the employees of hospitality and tourism industries in West Sumatera. Sample was elected by implementing non-probability sampling technique, specifically the purposive sampling technique. The respondents should be employees working in companies focusing on hospitality and tourism sectors in West Sumatera; such as hotels, restaurants, and tour travels. Since we used SEM-PLS as our data analysis technique, then the determination of minimum sample size was referred to Hair et al. (2014). Therefore, the size of the research sample was ten times of the number of paths on model, or 77 respondents.

Research variable operationalization is clearly stated in Table 1.

The research used measurement instruments in accordance with the previous research. Each indicators were measured by using 5-category Likert scale i.e. (1) strongly disagree, (2) disagree, (3) hesitant/neutral, (4) agree, and (5) strongly agree.

In general, the research was performed in two analysis steps that were descriptive analysis and hypothesis testing. Referring to the research problems, first, we conducted the descriptive analysis to observe the frequency distribution of respondents according to the observed demographical characteristics. Then, we applied data analysis technique to test the research hypotheses in two stages i.e. measurement model and structural model. Both stages were analyzed by using smartPLS 3.0 software, as the research models used were complex, multidimensional and consisted of many indicators (Ghozali, 2008). This research uses smartPLS according to Hullan (1999) which described PLS as one of the powerful statistical techniques due to its ability in model parameter and path estimation calculations during abnormal condition. In addition to that, it was suitable for small and medium sample sizes. Instrument testing (measurement model) was required to ensure the accurate result of research variable measurement, hence improving the scientific article quality (Cooper and Schindler, 2008). After testing the instrument, we tested the structural model to check all hypotheses proposed, and thus answering the research problems.

\section{RESULTS}

In accordance with Table 2, respondents' characteristics of 77 respondents in hospitality and tourism sectors in West Sumatera were mostly male (47 people, $61 \%$ ) and those aged $20-30$ year old (54 people, $70.1 \%$ ). Most respondents were senior high school graduates (55 people, $71.4 \%$ ); while average monthly income was less than IDR 4,000,000 (60 respondents, $78 \%$ ). It indicated that hospitality and tourism sectors (café, restaurant, hotel, and others) in West Sumatera has been dominated by young men. Running a business for men at a young age is one of the unique characteristics that is influenced by the cultural factors of the Minang tribe in West Sumatera. After graduating high school, men in Minangkabau at an early age are encouraged to be independent by going abroad from their villages or seeking their own business. This is evidenced by the many entrepreneurs in various sectors originating from the Minang tribe, including tourism businesses such as hospitality. According to Adya (2010), currently, many Minangkabau entrepreneurs are born who occupy the top layer to several companies that have listed their shares on the Indonesian stock exchange. even since the 1950s, many successful Minangkabau traders did business including Hasyim Ning, Rahman Tamin, Agus Musin Dasaad, and Sidi Tando. Some of the big hotel businesses that were successful in their time were Minang people, including Sofyan Hotel, Sentral Hotel, and Ambhara Hotel.

The research used PLS software to test indicator instrument validity of each variable used. Data processing technique for reflective construct testing on SEM-based variance using smartPLS tool had three criteria to assess validity and reliability i.e. convergent validity, discriminant validity, and composite validity. Convergent validity of the measurement model on reflective construct was assessed based on correlation between component/item scores. Meanwhile, result of validity testing was based on both convergent and discriminant validities whose indicators were tested in accordance with the loading scores obtained from algorithm process. Hair, Jr. et al. argued that outer loadings, average variance extracted (AVE), and composite reliability (CR) were parameters used to assess the convergent validity. Indicators were valid when the outer loading score was more than 0.70 , but still be acceptable when the AVE score was more than 0.50 . Reliability test was performed to observe 
to what extent the measurement tool had consistent measurement precision and accuracy from time to time. Practical regulation scores for Cronbach's Alpha and composite reliability should be more than 0.7 . However, 0.6 was still acceptable. Table 3 presents the result of reliability and convergent validity testing after two re-estimation stages (because AVE had not met the rules of thumb, so that invalid indicators were eliminated and re-running was conducted.

After performing the convergent validity test, we also tested discriminant validity by using Fornell Larcker's criterion parameter. Discriminant validity was necessary to indicate that latent variable or construct could predict the better block size. If the construct indicator correlation achieved higher score than the correlation between the indicators and another construct, then the construct had a high discriminant validity. Table 4 reveals that all indicators had the score of correlation between the constructs and tested variables higher than that between the constructs and other variables, hence the discriminant validity had been met.

Structural model consisted of latent constructs that could not be observed and had theoretical correlation. The testing included estimation of path coefficient that identified the correlation strength between dependent and independent variables. Structural model testing resulted in the significance value of the path correlation between latent variables by using bootstrapping function. PLS structural model was evaluated by using R-Square for dependent construct and path coefficient value or each path t-value for significance test on constructs in the structural model. In accordance with Ringle et al. (2015), we used Partial Least Squares (PLS) by smartPLS 3.0 software for hypothesis testing. Table 5 proposes the results of research hypothesis testing through bootstrapping process.

\section{DISCUSSION}

The results of data processing proved that correlation between the tested variables was significant and positive. The effects of internal environmental orientation and external environmental orientation on the green SCM was significant and positive, clarifying that both hypotheses were accepted. In line with the previous research concluding that internal environmental research influenced the green SCM (Chan et al. 2012), the research confirmed that internal environmental orientation significantly and positively affected the green SCM.

Green SCM was one of the important aspects that should be concerned by the company management. In the term of hospitality and tourism sectors in West Sumatera, the company had provided important understanding on environmental preservation to their employees. Almost all of hospitality and tourism sectors as cafés, restaurants, and hotels had managed waste well to maintain environmental preservation. In accordance to that, regarding the use of resources, they had established a good cooperation with trusted suppliers to ensure the product quality. In cafés, the main ingredients used were safe and free from dangerous chemical substance. Additionally, location and room layout of the cafés were also well conceptualized to make the tourists convenient. Furthermore, hotels had also paid much attention to the quality of water resources used by tourists. Companies had made a clear policy to build environmental awareness, such as by installing the caution banning people to throw garbage anywhere. It would indirectly affect the public behaviors of people that saw it, either those from internal parties or those from external ones. The better the internal environmental management in each hospitality and tourism sector, the better the green SCM concept implemented. Meanwhile, the employee attitudes of the industry played a significant role in the implementation of environmental preservation.

The research was in accordance with the research conducted by Chan (2010) (Banerjee et al., 2003) arguing that internal environmental orientation significantly and positively affected the green supply chain management. Additionally, it was in line with Chan et al. (2012) concluding that manager tended to assume the importance of responding to the stakeholder demand; such as getting involved in eco-friendly practice like GSCM. The managerial assumption could be defined as external environmental orientation (Banerjee, 2001), so that external environmental orientation could give positive effects to GSCM.

Referring to our research findings, there was a significant correlation between external environmental orientation and green SCM. External environmental indicated larger scopes than the internal one, but in the term of accountability, the latter one was more determining. When the internal part of hospitality and tourism sectors (café, restaurant, hotel, and others) were careless, it would impact on the external party. Moreover, hospitality and tourism sectors in West Sumatera had paid much attention to their external environment, since they believed that natural environmental development would greatly influence their business activities. Additionally, they also believed that political existence was influential, as indicated by the local government policy that encouraged either company director or manager to have commitment in the implementation of GSCM principles in their companies. In conclusion, external environmental orientation could affect GSCM implementation. Meanwhile, another important factor of external environment was the supplier. They provided the main necessities of each sector. Most cafés and restaurants in West Sumatera serving food for tourists had good food material quality, as it would affect the food taste. Besides, it would minimize dangerous or non-disposable waste. Furthermore, hospitality 
and tourism sector companies in West Sumatera had also established cross-function cooperation for environmental improvement.

\section{CONCLUSIONS}

In conclusion, both external and internal environmental orientations significantly and positively influenced the green SCM. It indicated that they could support the green SCM in hospitality and tourism industries. Meanwhile, company internal values and ethical standards on commitment to protect environment was necessary in the GSCM development practice. Manager should understand and had a clear commitment.

Besides, external environment also supported the green SCM in hospitality and tourism industries, where the manager perception on the needs to satisfy environment should be in accordance with the stakeholder demand. The implementation would help company save their resources and environmental preservation attempts. Finally, it could also create a good company image. Hospitality and tourism sector companies in West Sumatera had also established crossfunction cooperation for environment improvement.

The research can be used as the fundamental for the future research by developing other variables on different objects. Other mediating variables like economic and operational performance would be recommended to influence the green supply chain management. This research has limitation to investigate the respondents from employee in the hospitality and tourism sector. While, the implementation of GSCM also derived from other stakeholder perception in various manufacturing company such as: electrical, cosmetics, food and beverages sectors.. Hence, it can also be further developed by implementing GSCM from the managers, suppliers, governments, and customers perspective.

\section{REFERENCES}

Adinaya, G B. 2018. Perkembangan Pariwisata Indonesia dan Keterlibatan Masyarakat (in Bahasa). Accessed on https://nationalgeographic. grid.id/read/13948213/perkembangan-pariwisataindonesia-dan-keterlibatan-masyarakat?page $=$ all . April, 21st 2019.

Adya, Affandri. 2010. Perantau Minang di Jakarta (in Bahasa). accessed on October, 23th 2019.

Banerjee, S.B., 2001. Managerial perceptions of corporate environmentalism: Interpretations from industry and strategic implications for organizations. Journal of management studies, 38(4), pp.489-513.

Banerjee, S.B., Iyer, E.S. and Kashyap, R.K., 2003. Corporate environmentalism: Antecedents and influence of industry type. Journal of marketing, 67(2), pp.106-122.
Brochado, A., Rita, P. and Margarido, A., 2016. High tech meets high touch in upscale hotels. Journal of Hospitality and Tourism Technology, 7(4), pp.347365.

Chan, E.S., 2011. Implementing environmental management systems in small-and medium-sized hotels: Obstacles. Journal of Hospitality \& Tourism Research, 35(1), pp.3-23.

Chan, R. Y. K. 2010. Corporate Environmentalism Pursuit by Foreign Firms Competing in China. Journal of World Business 45(1): 80-92.

Chan, R.Y., He, H., Chan, H.K. and Wang, W.Y., 2012. Environmental orientation and corporate performance: The mediation mechanism of green supply chain management and moderating effect of competitive intensity. Industrial Marketing Management, 41(4), pp.621-630.

Cohen, S. and Roussel, J., 2005. Strategic supply chain management: the five disciplines for top performance. McGraw-Hill.

El-Masri, M., Orozco, J., Tarhini, A. and Tarhini, T., 2015, July. The Impact of IS-Business Alignment Practices on Organizational Choice of IS-Business Alignment Strategies. In PACIS (p. 215).

Green Jr, K.W., McGaughey, R. and Casey, K.M., 2006. Does supply chain management strategy mediate the association between market orientation and organizational performance?. Supply Chain Management: An International Journal, 11(5), pp.407-414.

Green Jr, K.W., Whitten, D. and Inman, R.A., 2008. The impact of logistics performance on organizational performance in a supply chain context. Supply Chain Management: An International Journal, 13(4), pp.317-327.

Green Jr, K.W., Zelbst, P.J., Meacham, J. and Bhadauria, V.S., 2012. Green supply chain management practices: impact on performance. Supply Chain Management: An International Journal, 17(3), pp.290-305.

Hashemi, S. H., Amir K. A., \& Tavana, M. 2015. An integrated green supplier selection approach with analytic network process and improved Grey relational analysis. International Journal of Production Economics, 159, 178-191.

Ho, D.C., Au, K.F. and Newton, E., 2002. Empirical research on supply chain management: a critical review and recommendations. International journal of production research, 40(17), pp.4415-4430.

Hulland, J. 1999. Use of partial least squares (PLS) in strategic management research: A review of four recent studies. Strategic Management Journal, Vol. 20 No. 2, pp. 195-204.

Jones, P., Hillier, D. and Comfort, C. 2014. Sustainability in the global hotel industry, International Journal of Contemporary Hospitality Management, Vol. 26 No. 1, pp. 5-17. 
Mahadeen, B., Al-Dmour, R.H., Obeidat, B.Y. and Tarhini, A., 2016. Examining the effect of the Organization's Internal Control System on Organizational Effectiveness: A Jordanian empirical study. International Journal of Business Administration, 7(6), pp.22-41.

Masa'deh, R.E., Alananzeh, O., Algiatheen, N., Ryati, R., Albayyari, R. and Tarhini, A., 2017. The impact of employee's perception of implementing green supply chain management on hotel's economic and operational performance. Journal of Hospitality and Tourism Technology, 8(3), pp.395-416.

Moori, R., Shibao, F. Y., \& Santos, M. R. dos. 2018. Role of technology in the environmental performance of the Brazilian chemical industry. Revista de Administração Mackenzie, 19(1). doi 10.1590/1678-6971/eRAMR180094.

Nicholls, S. and Kang, S. 2012. Going green: the adoption of environmental initiatives in Michigan's lodging sector, Journal of Sustainable Tourism, Vol. 20 No. 7, pp. 953-974.

Primasiwi, A. 2019. Prospek Pariwisata 2019: Persaingan Semakin Keras menjadi Tantangan Terbesar. Diunduh di https://www.suaramerdeka. com/travel/baca/133231/prospek-pariwisata-2019persaingan-semakin-keras-menjadi-tantanganterbesar. tanggal 21 April 2019.

Rao, P. and Holt, D., 2005. Do green supply chains lead to competitiveness and economic performance?. International journal of operations \& production management, 25(9), pp.898-916.

Ringle, C.M., Wende, S. and Becker, J.M. 2015. SmartPLS 3. Boenningstedt: SmartPLS GmbH.

Srivastava, S. 2007. Green supply chain management: a state of the art literature review. International Journal of Management Review, 9(1), 53-80.

Urquidi, Ana C, and Vicente M Ripoll. 2013. The Choice of Management Accounting Techniques in the Hotel Sector: The Role of Contextual Factors. Journal of Management Research 5(2): 65.

Volberda, H.W., van der Weerdt, N., Verwaal, E., Stienstra, M. and Verdu, A.J., 2012. Contingency fit, institutional fit, and firm performance: A metafit approach to organization-environment relationships. Organization Science, 23(4), pp.1040-1054.

Wem. 2018. Kemenpar Raih Gelar Menteri Terbaik, Pariwisata Jadi Sektor Idola Indonesia. Diunduh di https://breakingnews.co.id/read/kemenpar-raihgelar-menteri-terbaik-pariwisata-jadi-sektor-idolaindonesia. tanggal 21 April 2019.

Wijanarko, T. 2018. Pertumbuhan Pariwisata Indonesia Peringkat 9 Di Dunia. Diunduh di https://travel. tempo.co/read/1139099/pertumbuhan-pariwisataindonesia-peringkat-9-di-dunia/full\&view $=o k$. tanggal 21 April 2019.

Zhu, Q., Sarkis, J. and Lai, K.H., 2008. Confirmation of a measurement model for green supply chain management practices implementation. International journal of production economics, 111(2), pp.261273.

Table 1. Operational Definition of Variables

\begin{tabular}{|c|c|c|}
\hline VARIABLE/ DIMENSION & DEFINITION & INDICATORS \\
\hline \multicolumn{3}{|l|}{ Environmental Orientation } \\
\hline Internal & $\begin{array}{l}\text { The company's internal values and ethical } \\
\text { standards on the level of commitment to }\end{array}$ & $\begin{array}{l}\text { Joint efforts to preserve environment } \\
\text { Clear policy related to environmental awareness }\end{array}$ \\
\hline Chan et al. (2012) & protect environment & $\begin{array}{l}\text { Appreciation } \\
\text { The company value }\end{array}$ \\
\hline External & $\begin{array}{l}\text { Manager's perception on the need to satisfy } \\
\text { environment in accordance with the demand }\end{array}$ & $\begin{array}{l}\text { The effects on business activities } \\
\text { Financial welfare dependence }\end{array}$ \\
\hline Chan et al. (2012) & of external stakeholders & $\begin{array}{l}\text { The company sustainability } \\
\text { External stakeholders' expectation }\end{array}$ \\
\hline \multicolumn{3}{|c|}{ Green Supply Chain Management } \\
\hline $\begin{array}{l}\text { Internal Environmental } \\
\text { Management }\end{array}$ & $\begin{array}{l}\text { Practices to develop green supply chain } \\
\text { management as an organizational strategy } \\
\text { through imperative supports and commitment }\end{array}$ & $\begin{array}{l}\text { The senior manager's commitment } \\
\text { The intermediate-level manager's supports } \\
\text { Across-function cooperation }\end{array}$ \\
\hline Zhu et al. (2008) & $\begin{array}{l}\text { of both senior manager and intermediate-level } \\
\text { manager }\end{array}$ & $\begin{array}{l}\text { Total qualified environmental management } \\
\text { Environmental customization and audit programs } \\
\text { ISO } 14000 \text { certificate } \\
\text { Environmental management system }\end{array}$ \\
\hline Green Purchasing & $\begin{array}{l}\text { Cooperative attempts conducted by the } \\
\text { company and suppliers to minimize negative }\end{array}$ & $\begin{array}{l}\text { Eco-labeling product } \\
\text { Cooperation with suppliers }\end{array}$ \\
\hline Zhu et al. (2008) & environmental impacts on logistic activities & $\begin{array}{l}\text { Environmental audit } \\
\text { ISO } 14000 \text { certificate owned by suppliers } \\
\text { Eco-friendly evaluation practice } \\
\text { Provision of eco-friendly product design specification }\end{array}$ \\
\hline
\end{tabular}


Table 2. Frequency Distribution of Respondents' Characteristics

\begin{tabular}{llcr}
\hline Category & \multicolumn{1}{c}{ Description } & Frequency & Percentage \\
\hline Sex & Male & 47 & $61.0 \%$ \\
& Female & 30 & $39.0 \%$ \\
\hline Age & $17-20$ years old & 6 & $7.8 \%$ \\
& $20-30$ years old & 54 & $70.1 \%$ \\
& $31-40$ years old & 10 & $13.0 \%$ \\
& $41-50$ years old & 3 & $3.9 \%$ \\
& More than 50 years & 4 & $5.2 \%$ \\
\hline Last & Elementary school & 0 & $0.0 \%$ \\
education & Junior high school & 4 & $5.2 \%$ \\
& Senior high school & 55 & $71.4 \%$ \\
& Diploma I/II/III & 7 & $9.1 \%$ \\
& Bachelor & 11 & $14.3 \%$ \\
& Postgraduate & 0 & $0.0 \%$ \\
\hline Monthly & Less than IDR2,000,000 & 25 & $32.5 \%$ \\
income & IDR2,000,000 - IDR4,000,000 & 35 & $45.5 \%$ \\
& IDR4,000,001 - IDR6,000,000 & 8 & $10.4 \%$ \\
& IDR6,000,001 - IDR8,000,000 & 4 & $5.2 \%$ \\
& More than IDR8,000,000 & 5 & $6.5 \%$ \\
\hline
\end{tabular}

Tabel 3. Outer Model - Convergent Validity and Reliability

\begin{tabular}{cccc}
\hline Indicator & Outer Loadings & AVE & Composite Reliability \\
\hline GP1 & 0.848 & 0.798 & 0.952 \\
GP2 & 0.915 & & \\
GP3 & 0.911 & & \\
GP4 & 0.895 & & \\
GP5 & 0.895 & & 0.883 \\
\hline IEM1 & 0.689 & 0.520 & \\
IEM2 & 0.686 & & \\
IEM3 & 0.683 & & \\
IEM4 & 0.688 & & \\
IEM5 & 0.757 & & 0.865 \\
IEM6 & 0.749 & & \\
IEM7 & 0.789 & & \\
\hline OLE1 & 0.833 & 0.615 & \\
OLE2 & 0.751 & & 0.882 \\
OLE3 & 0.743 & & \\
OLE4 & 0.807 & & \\
\hline OLI1 & 0.759 & 0.653 & \\
OLI2 & 0.696 & & \\
OLI3 & 0.882 & & \\
OLI4 & 0.881 & & \\
\hline Sour SmatPL 3P1ma Da Process &
\end{tabular}

Source: SmartPLS 3 Primary Data Process

Table 4. Discriminant Validity - Fornell Larcker's Criterion

\begin{tabular}{lcccc}
\hline & $\begin{array}{c}\text { External Environmental } \\
\text { Orientation }\end{array}$ & $\begin{array}{c}\text { Green } \\
\text { Purchasing }\end{array}$ & $\begin{array}{c}\text { Internal Environmental } \\
\text { Management }\end{array}$ & $\begin{array}{c}\text { Internal Environmental } \\
\text { Orientation }\end{array}$ \\
\hline External Environmental Orientation & 0.784 & & & \\
Green Purchasing & 0.199 & 0.893 & 0.721 & 0.808 \\
Internal Environmental Management & 0.518 & 0.534 & 0.497 & \\
Internal Environmental Orientation & 0.267 & 0.393 & &
\end{tabular}

Table 5. Inner Model (Hypothesis Testing)

\begin{tabular}{ccc}
\hline Hypothesis & Original Sample & T-statistics $(|\mathrm{O} / \mathrm{STERR}|)$ \\
\hline Internal environmental orientation $\rightarrow$ Green SCM & 0.430 & 5.269 \\
External environmental orientation $\rightarrow$ Green SCM & 0.244 & 2.681 \\
\hline
\end{tabular}

Source: SmartPLS 3 Primary Data Process 